\title{
Identifikasi Usaha Konservasi Air Tanah Pada Kelurahan Bekasi Jaya Kecamatan Bekasi Timur
}

\author{
Shafira Adlina ${ }^{1}$, Alfiyatun $^{2}$, Hidayat Yorianta $^{3 *}$, Nita Noriko $^{4}$ \\ ${ }^{1,2,3,4)}$ Program Studi Biologi (Bioteknologi), Fakultas Sains dan Teknologi, \\ Universitas Al Azhar Indonesia, Jl. Sisingamangaraja, Jakarta 12110 \\ Tlp. 7244456, Fax. 7244767, *Penulis untuk korespondensi : yshidayat@ uai.ac.id
}

Abstract - The objective of this survey is to identify types of water conservation methods applied by the local government and the society at the Bekasi Jaya District (Kelurahan Bekasi Jaya), of the East Bekasi Region. Surveys were conducted at nine groups of households (Rukun Wilayah) that had history of flood during the rainy season and/or drought during the dry season. Questionnaires were used to collect information from 214 respondents. Additional data were collected through in-depth interviews with local authorities and few residents who were familiar with the water conservation activities in the region. This survey revealed that there is no proper conservation method applied in all studied areas. Lack of conservation efforts include both minimum activity of extension by the local authority on the important of water conservation, as well as applied conservation programs in the field. Only three households have some kind of water conservation method in place i.e. by making water collecting wells and ponds. However, these wells and ponds were not structurally up to the standard and need much improvement. As much as $46 \%$ of the respondents had flood experience. We identified several contributing factors to these water issue, among others : 1) High rate of population growth in this area; 2) Lack of water absorption areas (vegetative-covered areas); 3) River shallowness due to household wastes that were thrown into the river; and 4) The presence of building around the river banks. Active role of government to conserve water in this region and to develop this area with the principle of sustainable is absolutely required as should be done as soon as possible.
Keywords - Water conservation, Kelurahan Bekasi Jaya, District of Bekasi Jaya, Clean water, sanitation,Environment, Water absorption well, water reception ponds, vegetative-covered area.

\section{PENDAHULUAN}

A ir merupakan sumber kehidupan bagi seluruh makhluk hidup. Namun, jumlah air bersih yang tersimpan di ceruk bumi (aquifer) darat, laut, dan atmosfir, terus menerus berkurang jumlahnya karena kebutuhan manusia akan air semakin bertambah. Badan Pertanian Dunia (FAO) telah memperingatkan bahwa setidaknya lima miliar jiwa akan hidup dalam daerah yang amat minim air bersih di tahun $2025 .^{6}$ Pada saat ini, diperkirakan lebih dari 10 juta orang di dunia mengalami kesulitan mendapatkan air bersih menurut Drammeh UNEP (United Nations Environment Programme). Ke depan, diprediksi bahwa, kesulitan air bersih akan merembes ke sebagian besar negara-negara sedang berkembang. Pada tingkat yang akut, kekurangan air ini pada akhirnya dapat menyebabkan kegagalan dalam produksi tanaman-tanaman pertanian (panen) yang berdampak pada timbulnya konflik-konflik soaisl di daerah sekitar aliran sungai dan telaga. Untuk itu sangat diperlukan pengelolaan air bersih yang baik dan benar.

Apabila tidak segera dilakukan pengelolaan yang baik terhadap sumber-sumber air yang ada, prediksi pada tahun 2050 secara mencemaskan dikemukakan bahwa 1 dari 4 orang akan terkena dampak dari kekurangan air bersih (GardnerOutlaw and Engelman, 1997 dalam UN, 2003).

Pengelolaan dan penyediaan air bersih sangat berhubungan dengan tingkat sanitasi penduduk. Pada daerah-daerah dengan sumber air bersih yang baik, umumnya memiliki tingkat sanitasi yang baik juga. Hal sebaliknya terjadi apabila ketersediaan air 
bersih terbatas. Saat ini, rendahnya tingkat sanitasi dilaporkan mempengaruhi kurang lebih dari 2,4 miliar (40\%) penduduk dunia (WHO/UNICEF, 2000). Rendahnya sanitasi pada dasarnya berpengaruh pada semua tingkat usia, dari bayi hingga orang dewasa. Namun demikian, kelompok umur balita umumnya merupakan kelompok yang paling rentan terhadap penyakit-penyakit yang berhubungan dengan rendahnya sanitasi, seperti antara lain: muntaber, diare, disenteri, dll. Hal ini terbukti sebagaimana dilaporkan oleh WHO bahwa setengah dari jumlah ranjang rumah sakit di negaranegara sedang berkembang dihuni oleh balita yang menderita penyakit seperti disebut di atas.

Saat ini, kurang lebih 1,1 milyar penduduk dunia mengalami krisis air bersih (WHO/UNICEF,2000). Beberapa faktor utama yang menyebabkan terjadinya hal ini adalah: 1) Pengambilan air tanah secara berlebihan, terutama di daerah perkotaan yang menyebabkan penyusutan lahan-lahan pertanian; 2) Tingginya tingkat pencemaran terhadap sumber-sumber air; 3) Adanya konflik kepentingan ekonomi yang didukung oleh kebijakan yang kurang tepat, sebagai contoh: pembuatan perusahaan-perusahaan PAM yang mematikan sumur-sumur rakyat kecil bahkan sawah, dan menyebabkan masyarakat kecil mengambil inisiatif untuk merusak sumber mata air yang ada.; 4) Perusakan lingkungan dan sumbersumber mata air yang menyebabkan terjadinya kekeringan pada musim kemarau dan banjir pada musim hujan, dan terjadi secara konsisten, hampir setiap tahun setiap tahun.

Dengan melihat pada faktor-faktor di atas, kami melakukan penelitian ini, yang bertujuan untuk mengetahui sampai sejauh mana upaya konservasi air yang sudah dilakukan oleh masyarakat dalam rangka menaggulangi dan mencegah dampak masalah/krisis air seperti yang sudah dijabarkan di atas. Target lokasi penelitian adalah Kelurahan Bekasi Jaya, Kecamatan Bekasi Timur, Kota Bekasi, karena daerah ini sering mengalami masalah air seperti banjir dan kekeringan. Harapan kami, laporan ini dapat menghasilkan data dan informasi yang berkaitan dengan upaya-upaya (atau kurangnya upaya) untuk melakukan kegiatan konservasi air di daerah ini, sehingga dapat menjadi dasar dalam merencanakan program konservasi air di masa depan

\section{PEMBAHASAN}

\subsection{Usaha konservasi air tanah}

Konservasi air adalah pemanfaatan secara efisien penggunaan air yang tertampung dari air hujan atau upaya memanen hujan (Water harvesting) dengan cara menampung air hujan dalam suatu wadah sebagai cadangan air di musim kemarau. Konservasi juga bermanfaat untuk mengurangi volume aliran permukaan, laju erosi, sehingga dapat menurunkan laju degradasi lahan.

Hasil survey menunjukkan hanya 3 kepala keluarga (KK) dari 214 KK di Kelurahan Bekasi Jaya yang melakukan usaha konservasi air tanah. Dari ketiga KK hanya dua KK ini yang melakukan usaha konservasi air tanah berupa pembuatan sumur resapan, kelayakan sumur-sumur resapan ini pun masih dipertanyakan karena untuk menguji kelayakan sumur-sumur tersebut diperlukan pengkajian dan penelitian lebih lanjut. Satu keluarga lainnya membuat kolam resapan untuk upaya konservasi air, dan terbukti lingkungan rumahnya tidak pernah mengalami banjir, berbeda dengan rumah-rumah di sekitarnya yang sering mengalami banjir karena tidak memiliki area resapan air. Warga yang memiliki kolam resapan ini tergolong warga dengan tingkat pendidikan tinggi (Sarjana S1) dan berprofesi sebagai pegawai pemerintahan Kota. Walaupun pada kenyataannya, konstruksi sumur atau kolam resapan yang sudah dibuat oleh warga masih jauh dari konstruksi ideal, sehingga tidak mampu mengatasi masalah air secara optimal. Konstruksi kolam resapan yang dibuat warga hanya berupa kolam dengan dasar kolam yang penuh retakan sehingga hanya dapat menyerap air yang menggenang (Gambar 1). Konstruksi sumur resapan yang ideal sebaiknya memiliki sistem penyaringan air dan kelebaran lubang sumur yang standar

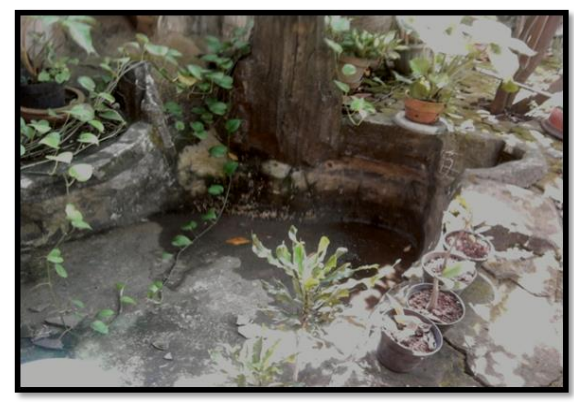

Gambar 1. Kolam resapan air yang dibuat oleh di salah satu rumah warga RW V 
Sumur Resapan pada umumnya berfungsi sebagai pengendali banjir. Penggunaan sumur resapan mampu memperkecil aliran permukaan sehingga menghindari penggenangan. Selain itu, sumur resapan memberi manfaat untuk memperbaiki ketersediaan air tanah atau mendangkalkan permukaan air sumur, sehingga menambah jumlah air dalam tanah.

Sebagai upaya penanggulangan banjir, di sungai RW XI Pemerintah setempat telah membangun unit pompa air (Gambar 2). Keberadaan unit pompa air ini ditujukan untuk memindahkan genangan air dari lingkungan warga ke sungai. Tapi walaupun sudah terdapat mesin pompa ini, kejadian banjir di RW XI masih kerapkali terjadi. Hal ini diprediksikan terjadi karena kondisi sungai yang sudah dangkal dan menyempit.

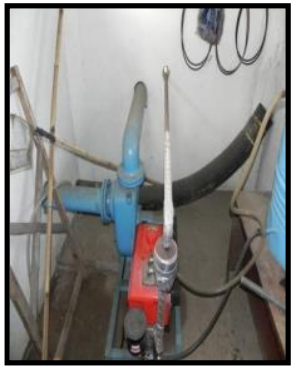

A. Mesin Pompa

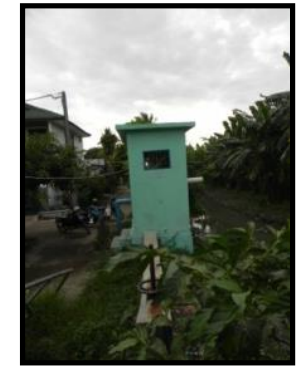

B. Rumah mesin

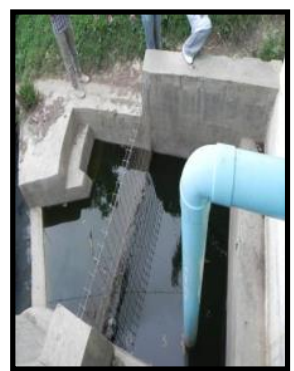

C. Pipa penyedot air

Gambar 2. Lokasi penggambilan gambar di RW 11: A. Mesin pompa air yang ditempatkan di pinggiran sungai oleh pemerintah RW setempat. Hal ini dimaksudkan untuk menanggulangi kejadian banjir di RW tersebut.

B. Rumah mesin pompa. C. Pipa penyedot air, saat air banjir di jalanan sekitar rumah warga sudah meninggi, maka pipa penyedot air akan menyedot genangan air dan membuangnya ke sungai.

\subsection{Masalah air}

Hasil survei menunjukkan sekitar $63 \%$ KK mengalami kesulitan air bersih, dan $34 \%$ kepala keluarga mengalami kesulitan air tanah. Dari hasil wawancara oleh beberapa kepala keluarga ditemukan bahwa mereka mengalami kesulitan air bersih pada saat musim hujan dan kesulitan air tanah di musim kemarau. Diantara masalah air sumur yang dialami warga antara lain, air berminyak, berbau logam (besi) dan kekeringan.

\subsection{Sumber air}

Data survei menunjukkan bahwa sebagian besar penduduk Bekasi banyak menggunakan sumur, yaitu sekitar $109 \mathrm{KK}, 61 \mathrm{KK}$ lebih memilih menggunakan sumber mata air dari PDAM dan sebanyak $51 \mathrm{KK}$ menggunakan sumber mata air dari keduanya, baik sumur maupun PDAM. Dapat dilihat bahwa mayoritas penduduk kelurahan Bekasi Jaya umumnyamenggunakan menggunakan sumber mata air sumur; dengan kata lain terindikasi adanya penyedotan air tanah yang berlebihan.

Secara teknis dampak pemompaan air tanah yang berlebihan mengakibatkan antara lain:

\section{Intrusi Air Laut}

Penyedotan air tanah yang berlebihan menyebabkan berkurangnya air tanah yang digantikan oleh air laut yang merembes masuk (intrusi), terutama di daerah-daerah sekitar pesisir pantai. Tingkat intrusi meningkat di daerah dengan populasi penduduk padat dan kawasan-kawasan industri seperti di kota-kota besar yang banyak menyerap air tanah.

\section{Penurunan Permukaan Tanah}

Penurunan tanah (land subsidence) didefinisikan sebagai penurunan permukaan yang antara lain disebabkan oleh faktor, pengambilan air tanah yang berlebihan. Sebagai akibat penurunan tanah, menyebabkan kerusakan pada bangunan dan struktur seperti retak-retak dan amblasan, pembalikan arah sistem drainasi dan meningkatkan kemungkinan terjadinya bencana banjir.

Sebagai contoh terbaru di ibukota adalah turunnya sebagian ruas jalan RE Martadinata Jakarta Utara sepanjang 107 meter pada pertengahan September lalu. Beberapa contoh lainnya seperti bergesernya kondisi sambungan Jembatan Cibodas sekitar $5 \mathrm{~cm}$ di Jalan Gatot Subroto, Yang menyebabkan dinding sandaran menjadi dan aspal jalan menjadi meregang dan mengalami penurunan sejauh $20 \mathrm{~cm}$. (Media Indonesia, 29 Oktober 2010)

\section{Penurunan Tingkat Air Tanah}

Pada saat ini dengan rusaknya hutan dan hilangnya daerah resapan air, muka air tanah menjadi semakin berkurang/menurun. Karena ratio antara input dan output air dalam tanah 
tidak berimbang sebagai akibat kegiatankegiatan yang disebutkan di atas, penduduk sering kali mendapati sumur-sumur mereka semakin dalam dan jumlah air semakin berkurang.

\section{Kekeringan}

Dampak lainnya dari eksploitasi air tanah yang berlebihan adalah terjadinya kekeringan di musim kemarau. Tidak optimalnya konservasi hutan, dalam jangka panjang ikut memperburuk keadaan ini, karena kehilangan air sebagai akibat aktifitas manusia tidak diimbangi dengan pemasokan air untuk menggantikan air yang terambil.

\section{Penurunan Kualitas Air tanah}

Sebagai akibat pengambilan air tanah dengan menyedot air tanah secara berlebihan, khususnya daerah perkotaan, menyebabkan terjadinya kekosongan pada lapisan-lapisan tanah yang telah terambil air tanahnya. Lapisan-lapisan kosong ini dapat digantikan oleh bahan-bahan pencemar yang merembes masuk. Akibatnya, kualitas air tanah secara signifikan berkurang, bahkan dalam keadaan ekstrim di daerah perkotaan, air tersebut tidak lagi dapat digunakan untuk kegiatan sehari-hari (MCK).

Dari hasil survei didapatkan fakta bahwa 46 persen responden ternyata pernah mengalami kasus banjir yang keseluruhan kasus banjir ini masih sering terjadi hingga saat ini. Sebagian besar fenomena banjir terjadi pada daerah/RW yang padat penduduk, seperti RW V, RW II, RW VII, RW VIII dan RW XIV. Karena minimnya lahan terbuka hijau sebagai area infiltrasi air hujan, menyebabkan saat turun hujan air akan tergenang dan menimbulkan banjir.

Daerah pemukiman yang rawan banjir ini, merupakan daerah dengan pertumbuhan pemukiman yang relatif cepat. Sebagian besar area warga sudah ditutup dengan semen yang dapat menghalangi terserapnya air ke dalam tanah. Sebagai media penyalur air hujan ke kali, warga mengandalkan sistem selokan. Namun, kenyataan di lapangan justru banyak selokan yang tidak terawat dan tersumbat karena budaya membuang sampah di selokan yang sampai saat ini sulit dihilangkan. Beberapa ketua RT yang menggalakkan program selokan bersih dengan menutup selokan agar tidak dijadikan tempat membuang sampah, namun karena upaya ini tidak sepenuhnya didukung oleh warga sehingga fenomena banjir akibat meluapnya air selokan tetap masih sering terjadi.

Pada beberapa kasus, untuk RW VII, RW VIII, RW XIII, RW XIV banjir lebih disebabkan oleh letak pemukiman warga yang terlalu dekat dengan kali (bantaran kali). Kondisi ini membuat kali menyempit akibat perluasan lahan dan menjadi lebih dangkal sebagai akibat endapan lumpur dan sampah. Pada saat musim penghujan kali tidak akan mampu menampung air hujan, hingga terjadilah banjir. Kerusakan DAS (Daerah Aliran Sungai) menyebabkan kemampuan lahan menyimpan air menjadi berkurang sehingga air hujan yang jatuh tidak dapat ditahan oleh tanah dan langsung dialirkan kembali ke laut. Berkurangnya area daya tampung tersebut menyebabkan banjir saat musim hujan dan sebaliknya, kekeringan di musim kemarau.

Untuk RW II yang menjadi penyebab banjir, berbeda dengan RW yang lain. RW ini terletak di daerah dengan topografi yang relative lebih rendah dibandingkan wilayah di sekitarnya. Walaupun pada RW ini terdapat lahan terbuka yang cukup luas, namun banjir tetap sering terjadi. Bedasarkan hasil wawancara diketahui bahwa, pada daerah ini terdapat parit pembuangan air dari lingkungan sekitar. Parit diarahkan dan tepat berakhir di kali kecil pada RW ini. Pada saat turun hujan parit ini akan meluap dan menyebabkan banjir.

Dari total 214 responden $45 \%$ berpenghasilan 500.000 - 1.000 .000 rupiah perbulan, 21\% kurang dari 500.000 dan hanya $1 \%$ masyarakat yang memiliki pendapatan lebih dari 5.000.000 rupiah per bulan. Dari data tersebut dapat diketahui bahwa mayoritas masyarakat Kelurahan Bekasi Jaya merupakan masyarakat dengan tingkat ekonomi relatif rendah (pendapatan keluarga Rp. 500.000,00 - Rp. 1.000.000,00 per bulan). Sehingga, perlu peranan dari pemerintah setempat untuk mendanai kegiatan konservasi air maupun upaya untuk menganggulani banjir di Kelurahan ini

\section{METODE PENELITIAN}

Penelitian ini dilakukan di Kelurahan Bekasi Jaya, Kecamatan Bekasi Timur, Kota Bekasi. Pengumpulan data primer dalam penelitian ini dilakukan dengan cara survey terhadap 214 orang responden yang tinggal di $9 \mathrm{RW}$. Berdasarkan informasi yang kami terima dari pihak pemerintah di tingkat kelurahan, ke 9 RW ini merupakan RW yang banyak mengalami masalah banjir dan pengadaan air bersih. Pengambilan sampel dilakukan dengan langsung mewawancarai 
penduduk dan observasi lapangan. Wawancara dilakukan dengan mengisi kuisioner yang telah dipersiapkan sebelumnya. Sebagai data tambahan, dilakukan juga wawancara mendalam (indepth interview) kepada sekretaris desa dan staff kantor kelurahan yang mengetahui secara umum permasalahan air di Kelurahan Bekasi Jaya dan berbagai kebijakan konservasi air di daerah tersebut.

Pengumpulan data primer ini menggunakan pedoman wawancara (interview guide) yang dibantu dengan kamera dan pencatatan. Data yang dikumpulkan dalam penelitian ini meliputi data kualitatif dan data kuantitatif. Data kuantitatif dianalisis dengan menghitung persen (\%)dari hasil tabulasi frekuensi dan diolah dengan menggunakan statistik sederhana (mean, median, standard deviation). Sementara analisis data kualitatif dilakukan secara deskriptif analitik terhadap transkrip hasil wawancara terhadap informan.

\section{PENUTUP}

\subsection{Kesimpulan}

- Belum ada upaya konservasi air yang memadai yang dilakukan oleh pemerintah daerah di wilayah Kelurahan Bekasi Jaya, baik dalam bentuk penyuluhan kepada masyarakat maupun aksi langsung di lapangan.

- Hanya tiga KK yang sudah melakukan konservasi air. Satu KK membuat sumur resapan, dan dua lainnya membuat sumur resapan. Namun demikian, perlu dicatat bahwa sumur dan kolam resapan yang dibuat warga secara struktur masih belum memadai.

- Empat puluh enam persen $(46 \%)$ warga pernah mengalami banjir akibat pertumbuhan pendudukyang sangat tinggi dan menyebabkan berkurangnya lahan resapan, mendangkalnya sungai sebagai akibat kebiasaan membuang sampah ke sungai serta pendirian bangunan di bantaran kali.

- Empat puluh lima persen (45\%) warga berpenghasilan Rp. 500.000,00-Rp. 1.000.000,00 per bulan, dan dapat digolongkan pada kelompok sejahtera (hampir berkecukupan), namun untuk melakukan upaya konservasi air yang berkelanjutan dan memadai tetap diperlukan peranan Pemerintah dalam hal pendanaan dan pencerdasan masyarakat disamping kesadaran dari masyarakat untuk peduli terhadap lingkungan.

\subsection{Saran}

\section{Pengisian Air Alami (Natural Recharge)}

Sangat dibutuhkan kerjasama yang serius di antara pihak-pihak yang berkepentingan, yakni: masyarakat setempat dan Pemerintah. Karena ulang secara alami terhadap rongga-rongga tanah yang kosong dapat terjadi pada tanah yang emiliki tingkat hijauan (vegetasi) tinggi, maka pihak-pihak tersebut harus bekerja sama untuk menyediakan lahan hijauan khusus yang dilindungi untuk mejadi daerah resapan air tanah. Selain itu pelestarian hutan terutama di daerah penyangga (buffer zone) harus terus dipertahankan dan ditingkatkan.

\section{Pengisian Air Buatan (Artificial Recharge)}

Berbagai teknologi dalam upaya pembuatan pengisian buatan telah banyak dilakukan, beberapa contoh adalah danau buatan dan sumur resapan (recharge well/injection well).

Sebagai bentuk upaya untuk mengatasi kejadian banjir di Kelurahan Bekasi Jaya, perlu dilakukan upaya yang serius dari banyak pihak. Terutama dari pihak pemerintah dan perlu didukung oleh mayarakat.

\subsection{Ucapan Terima Kasih}

Puji dan syukur kami panjatkan kehadirat Allah SWT, berkat RahmatNya kegiatan penelitian ini dapat terlaksana di Kelurahan Bekasi Jaya, Kecamatan Bekasi Timur. Kegiatan penelitian ini dapat terselenggara berkat bantuan dana dari LP5M UAI. Untuk itu kami mengucapkan banyak terima kasih atas kepercayaan LP5M kepada kami. Tim peneliti juga mengucapkan terima kasih terutama kepada para responden dan informan dalam penelitian ini yang telah bersedia meluangkan waktunya untuk memberikan informasi kepada tim peneliti. Tak lupa juga rasa hormat kami sampaikan kepada pihak pemerintah Kelurahan Bekasi Jaya yang telah bersedia memberikan data dan informasi tentang kondisi dan masalah air di Kelurahan Bekasi Jaya. 


\section{DAFTAR PUSTAKA}

[1] Anonim.http://senthong.wordpress.com/2009/09/0 2/kuantitas-dan-kualitas-ruang-terbuka-hijau-rthdi-permukiman-kota/ (diakses pada 13 Maret 2010)

[2] Anonim.http://hiin.facebook.com/topic.php?uid $=77797533807 \&$ topic $=9227$ (diakses pada 13 Maret 2010)

[3] Anonim.http://digilib.itb.ac.id/gdl.php?mod=brows e\&op=read\&id=jbptitbpp-gdl-mesishinta-33412 (diakses pada 13 Maret 2010)

[4] Anonim.http://www.litbang.deptan.go.id/artikel/on e/38/pdf/Bagaimana\%20Memasyarakatkan\%20Ko nservasi\%20Air.pdf (diakses tanggal 19 Februari 2010)

[5] Beyda, inon. 2002. KONSERVASI TANAH DAN AIR DI INDONESIA KENYATAAN DAN HARAPAN. USU digital library. Fakultas Ilmu Sosial dan Ilmu Politik Jurusan Ilmu Komunikasi, Universitas Sumatera Utara . (diakses pada 13 Maret 2010)

[6] Emka,Heru.http://www.wawasandigital.com/index. php?option $=$ com_content\&task $=$ view $\&$ id $=32163 \&$ Itemid=62 --, Aktivis Forum Studi Mitra Edukasi (diakses tanggal 18 Februari 2010)

[7] Frost, Helen. 1999.Keeping Water Clean. Pebble Books.

[8] Hadi,Surjono Sutjahjo. 2010..Kelangkaan Air Picu Krisis dan Bencana. Antara News, Jatim (diakses pada 13 Maret 2010)
[9] Kadri, T., 2003. Partisipasi masyarakat dalam mewujudkan suplai Air bersih di perkotaan. Makalah Pengantar Falsafah Sains, Program Pasca Sarjana/S3 Institut Pertanian Bogor, tidak diterbitkan.

[10] Mariana Raini, Ani Isnawati, Kurniati. 2004. Kualitas Fisik dan Kimia Air PAM di Jakarta, Bogor, Tanggerang, Bekasi Tahun 1999-2001. Media Litbang Kesehatan XIV (3):14-19

[11] Nur, Mohamad Rokhudin. "Krisis Air Bersih Akibat Kepadatan Populasi". http://paknoer.blogspot.com/2010/02/akibat-kepadatanpopulasi 05.html (diakses pada 13 Maret 2010)

[12] Parwati, Sisilastuti, I Made Putrawan.2009. Model Hubungan Penduduk dan Konversi Lahan Dengan KetersediaanAir Bersih Untuk Perencanaan Pengelolaan Sumber Daya Air Melalui Metode System Dynamics di Kabupaten Bekasi. Jurnal Bumi Lestari 9(2): 138:150.

[13] Ridha,Alwan.3 Februari 2010.15 Tahun Lagi, Jakarta Krisis Air Tanah. Harian tempo. (diakses pada 13 maret 2010)

[14] Sugiyono. 2003. Statistika untuk Penelitian. Bandung: CV Alfabeta.

[15] Supranto,J.2000. Statistika: Teori dan Aplikasi. Jakarta: Erlangga.

[16] Thahja,Surna. 2001. Untuk Generasi Masa Depan: Pemikiran dan Permasalahan Lingkungan. Jakarta: Aksara Buana

[17] Thomas Triadi Putranto, Kristi Indra Kusuma.2009. Permasalahan Air pada Daerah Urban. TEKNIK 30 (1):48-51 